\title{
Excursions
}

Volume 10, Issue 1 (2020) | Chaos

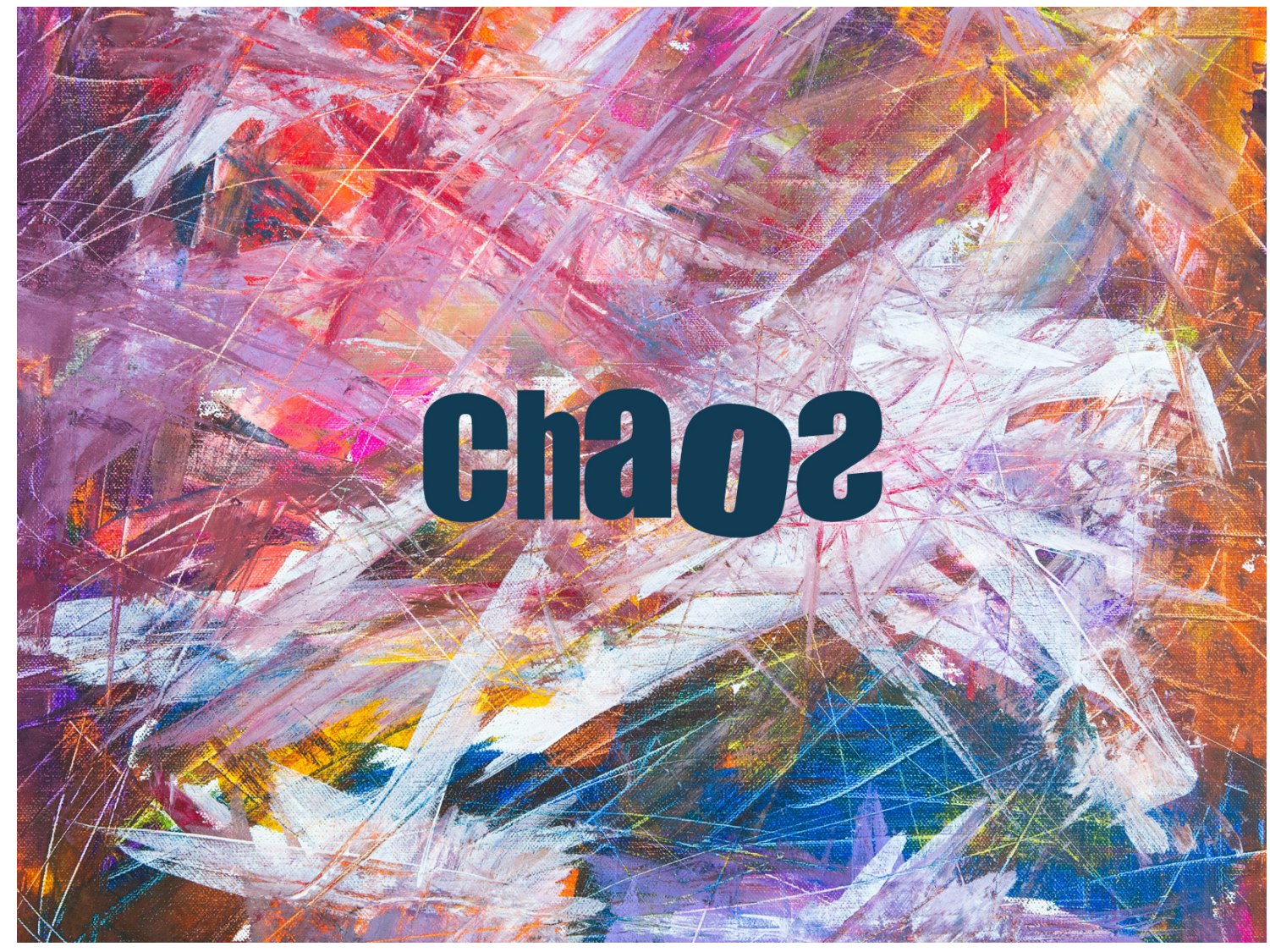

Cover photo: Unbennant \#3 by Felix Spiske | Photo by Markus Spiske on Unsplash

\section{Farah Alrajeh}

Creativity as a Response to Chaos: Innovation and Imagination in Post-2003 Iraqi Literature and Art 


\title{
Creativity as a Response to Chaos: Innovation and Imagination in Post-2003 Iraqi Literature and Art
}

\author{
Farah Alrajeh \\ University of Sussex
}

\begin{abstract}
My study focuses on Iraq, and, more specifically, on the creative works of fiction and art that emerged in the years following the 2003 US invasion when chaos became a reality. Analysing these works will show how their emergence and flowering during the period after the war, as well as the decades of censorship and stagnation prove the existence of a viable connection between chaos, creativity, and knowledge. In other words, I will show how the violence and disorder in the post-war period stimulated creativity in two Iraqi authors and artists. [...] Their works show how imagination can spring from chaos to describe it, embrace it, or suggest certain ways to resist it.
\end{abstract}

\section{Introduction}

Chaos is defined by the Cambridge Dictionary as a state of total confusion with no order. What gives chaos negative connotations is that it usually follows disasters, wars, and historical disturbances. Religious traditions from different parts of the world associate God with order and celebrate the victory over chaos in their rituals and myths. For example, in the ancient religion of Babel, the Mesopotamian creation myth Enuma Elisha (also known as The Seven Tablets of Creation), recounts the birth of the gods and 
the creation of the universe and human beings out of "undifferentiated water swirling in chaos" (Mark, 2018). It narrates events of a battle in which Marduk, the God of the sky, defeats Tiamat, a female god-figure associated with chaos, then divides her body to form the world. Tiamat has been interpreted as referring to an older impotent order of society and divine beings that is replaced by the new.

Chaos, or its female incarnation Tiamat, was defeated by the Babylonian king. However, the myth alludes to the fact that chaos can be a ground from which creative and new things spring. This is because the body of the goddess of chaos had been used to create an orderly system and new life:

\begin{abstract}
Marduk defeats Quingu and kills Tiamat by shooting her with an arrow which splits her in two; from her eyes flow the waters of the Tigris and Euphrates Rivers. Out of Tiamat's corpse, Marduk creates the heavens and the earth, he appoints gods to various duties and binds Tiamat's eleven creatures to his feet as trophies (to much adulation from the other gods) before setting their images in his new home (Mark, 2018).
\end{abstract}

Other religions encourage an acceptance of chaos or elements associated with it, such as negativity, unknowing, emptiness, and darkness. For example, in the The Texts of Taoism, it is mentioned that in ancient China, early Daoist (Taoist) texts support mystical union with hun-tun (chaos) and identify hun-tun with the ultimate principle of Dao: "In the Grand Beginning of all things there was nothing in all the vacancy of space. There was nothing that could be named. It was in this state that there arose the first existence" (Legge, 1962, p. 20). Similarly, along with the mainstream Vedic traditions of India, there are Upanishadic and Buddhist doctrines that encourage a unification with 'emptiness', another element of chaos (Omvedt, 2003).

Denis Edwards (2020) mentions that "[chaos] can be a threat and a challenge. But it can also have the character of the mysterious and 
uncontrollable ground or source from which all things spring. It can represent the possibility of creativity and of the new". Similarly, in his No Creativity Without Chaos, Peter Lloyd (2019) explains the relationship between chaos and the creation of the universe. He adds that chaos has been a motif for creativity, knowledge, and change:

\footnotetext{
Everything in the universe arises from the struggle between Cosmos and Chaos. Just as surely as random mutation drives evolution, chaos drives creativity. To generate more truly unique ideas and to solve problems more effectively, get in sync with the universe. Invite chance, welcome randomness, embrace chaos.
}

The connection between chaos and individual creativity has been noted from a psychoanalytic point of view. Carlos Antonio Torre (2014) points out that "the brain needs to be chaotic in order to perform the problem-solving function for which it was designed [and that] through such chaotic dynamics, problem-solving efforts can evolve into novelty and creativity" (p. 186). Torre adds that any chaotic situation will "give birth to new ideas, new knowledge, the emergence of new patterns of interaction or forms of organisation" (ibid).

In the West, an extensive body of scholarship that focuses on chaos and deals with it as a separate field of knowledge has evolved and developed. In Chaos and Order, the literary theorist Katherine Hayles (1991) elucidates how chaos has become "an emerging field known as the science of chaos" (p. 1). She adds that the new "paradigm of orderly disorder" (p. xiii), represented by chaos theory, signifies a conceptual revolution in modern culture. Chaos theory, thus, has found enthusiasm and full reception in the field of humanities and other scientific fields as mathematics and physics.

Arab/Islamic societies alternatively view chaos through a negative lens and consider it as a source of disorder and destruction. Generally, Muslims believe in the emanation of the universe from eternity, not from chaos, as other ancient religions suggest. According to Islam, the world was 
eternal but temporary in essence, and the will of God created it (al-Alousi, 1968, p. 179). In his Islamic Mythology, David Leeming (2005) points out that "Islam is a religion that is more concerned with social order and law than with religious ritual and myths" (pp. 207-211). Arab Muslim thinkers believe that chaos is a source of evil and corruption to society and culture. For example, the Egyptian Islamic thinker Mahmood Shakir claims that "Chaos is a big evil, no wise can doubt this, and this evil cannot produce any good, as some people claim" (Jamal, 2003, p. 831). Shakir has not only negated the positive effects of chaos but concludes that the literature produced during the spread of chaos should be disposed of. The rejection of the idea that chaos can bring creative and unique knowledge explains the lack of Arabic literature and scholarship on chaos as a source of creativity. Reviewing the Arabic and Iraqi scholarship written on the theme of chaos, I have not identified any study that looks at chaos as a source of creativity and imagination.

In this article, I attempt to fill the gap in the literature by identifying chaos as a motive for creativity and knowledge. To do this, my study focuses on Iraq, and, more specifically, on the creative works of fiction and art that emerged in the years following the 2003 US invasion when chaos became a reality. Analysing these works will show how their emergence and flowering during the period after the war, as well as the decades of censorship and stagnation prove the existence of a viable connection between chaos, creativity, and knowledge. In other words, I will show how the violence and disorder in the post-war period stimulated creativity in two Iraqi authors and artists. First, Frankenstein in Baghdad (2018) by Ahmad Saadawi, which shows the emergence of a new wave of literature that looks at war, violence and chaos from a new perspective. Second, The Return of Baghdad's Storks painting by Mahmoud Fahmi to explain the development of a new wave of artistic works after the war. 
Destructive or Creative Chaos? Iraq in post-2003 US war: A Historical Glimpse.

Since the US forces blasted their way through Baghdad in 2003 and toppled the Iraqi regime of Saddam Hussein (1979-2003), the promise of imposing democracy and freedom was more of an illusion than a reality. Iraq slipped into a state of chaos and a series of violent events that impacted the development of the economic, cultural, and social fabric of the country. This was particularly so when the production of literature and art had nearly disappeared altogether in the years that followed the war.

During the decades that preceded the 2003 war, literature, art, and the media were utilised by the government for political propaganda and ideological commissions. The war with Iran (1980-1988), the Gulf war (1990), and atmosphere of repression and censorship suffered by Iraqi authors and artists affected their creativity and freedom of expression. Literary topics and artistic works were limited to themes of war and ancient history. Writers had to employ the fantastic and symbolic to avoid the regime's censorship as pointed out by the Iraqi novelist Hayfa Zangana (2007):

\footnotetext{
Writers inside Iraq survived the wars and brutality of the regime either by resorting to silence, or by continuing to write but relying on allegory or mysticism. The characters were extracted from ancient history. Gilgamesh could be found walking relentlessly in the narrow alleys of Baghdad; Nebuchadrezzar, the warrior king of Babylon, returned from the ancient past to claim endless victories in the Iran-Iraq War (19801988) (p. xiii).
}

Describing the suffering of Iraqi authors inside Iraq and the negative consequences of censorship and control on fiction, Salam Ibrahim (2012) explains:

Under the dictatorship, the novelist at the instant of writing suffered from the syndrome of self-censorship. Words might lead to assured death, as was the case with the novelists Mahmud Jandari and Hasan 
Mutlaq. All this made the novel weak, treating everything unessential in the experience, preoccupied with unimportant details, old history, regular social worries that had nothing to do with the daily confrontations of death [...] All this impacted the structure of the novel, which emerged weak, confused and immature (p. 8).

Literature and art had to glorify the regime and valorise war to guarantee the safety of the author, including, for example, the series by Qādisiyyat Saddam (in reference to the Iran-Iraq war) entitled Qisas tahta laheeb al-naar (Stories Under the Flame of Fire, 1983). The situation was the same in Iraqi cinema as claimed by Aseel Kami: "Films focused mainly on the 1980-88 Iraq-Iran war, portraying Iraq as the victor in the conflict, which ended in a stalemate and ceasefire. The film 'The Long Days' told Saddam's life story" (Reuters 2012). These challenging circumstances show how Iraqi authors and artists lived under strict control and had limited space for creativity and imagination. This narrowed the publishing opportunities for Iraqi writers in other languages outside Iraq and decreased their opportunities to reach Arab and global audiences.

The literature of post-2003 Iraq

During the years that followed the 2003 war, a new wave of writing has emerged that probes subjects relating to war, corruption, and violence in addition to focusing on the failure of the post-2003 Iraqi government in dealing with the crisis. These writings have employed the knowledge and experience that accompanied the years of chaos and introduced a new type of fiction that subverts the traditional ways of writing through challenging censored topics and artistic elements as confirmed by the Iraqi critic Shakir Mustafa (2008):

Iraq's troubles, nevertheless, have energised its literary scene. Writing under the kind of relentless surveillance the country has suffered since the early 1970 s gradually stagnates creativity, and it fell to events of historical proportions to help writing in Iraq escape the confines of 
mundane themes and treatments. National catastrophes are not necessarily beneficial to creative expression; indeed, they can be quite detrimental, but in Iraq, they have opened up new terrains, and narrative writing has flourished (pp. xiii-xiv).

The rise of a new type of literature in post-2003 war shows how Iraqi authors have embraced chaos and presented a new literary experience. For example, the novels of Ali Bader that recounts the history of Iraq from the perspective of the victims and marginals; the narratives of Hasan Blasim that portray reality through the employment of magical realism and black humour; and Ahmad Saadawi's novels that mixes fantasy with the real to comment on the devastating effects of war. To show how authors are responding to chaos with imagination, I promote Saadawei's novel Frankenstein in Baghdad as a key example.

Ahmad Saadawi (1973) is an Iraqi novelist, journalist, and caricaturist who started his literary career during the 1990 s when Saddam Hussein's regime was still in power. Saadawi, like many other writers from his generation, suffered from the state's censorship and witnessed first-hand the war and violence that ravaged his country. His work as a reporter for the BBC Arabic between the years 2005-2007 put him in daily contact with the suffering of the ordinary people. Saadawi saw how the war placed Iraq in a state of violence and chaos where human rights abuses occurred. The war widened the social schism, dragging the country into sectarian violence/war between 2005-2008, costing hundreds of innocent lives (Arango, 2013) realities of the loss, destruction, and failures of the 2003 war have not been completely document in the news nor in political reports. Saadawi has attempted to counter these shortcomings by highlighting that

there have been numerous films and TV shows on Iraq and the war, but their heroes are American. The Iraqis were in the background. What we'll do with this film is to flip the narrative around. In the book, there's no American hero. Our heroes are Iraqis (Hankir, 2018). 
Saadawi's novel Frankenstein in Baghdad demonstrates how chaos and disorder can motivate authors' imagination and revive the power of writing. The narrative offers readers a sarcastic critique of the war and the disorder that followed to its disastrous, lingering consequences. It calls Iraqis to think of how to reorder their lives, fight violence, and reject sectarianism. The novel echoes Mary Shelly's Frankenstein (1818) as it reintroduces the monstrous character in a contemporary Iraqi context. The protagonist of the story is a creature called 'Whatsitsname'. His body is made of scattered parts of dead victims of the war. He rises to life when the soul of one of the victims of a car explosion gets into his body. He embarks on a journey of revenge on behalf of those whose organs constitute his body.

Frankenstein in Baghdad identifies how chaos and destruction can stimulate creativity and innovation. Saadawi's work as a news reporter during the sectarian violence in post-2003 Baghdad sparked the idea of this novel. While reporting in one of Baghdad's hospitals, Saadawi witnessed a traumatic scene where the corpses of victims of an explosion were scattered in a morgue, and people were desperately searching among body parts for their relatives. Later, Saadawi uses this incident to write his novel, which shows how he employs chaos as a theme and character:

\footnotetext{
A young man walked into the morgue, Saadawi recounts, demanding to see the corpse of his brother, who'd just been killed by a bomb. The man in charge at the morgue led the grieving brother to a room filled with assorted limbs, casually pointing to one body part in the corner. The man wailed, asking where the rest of his sibling's mutilated body was, to which the desensitised morgue manager said while waving his hand around the rest of the room, "take what you want and make yourself a body" (Hankir 2018).
}

The monster can be seen as a metaphor for the chaos of the war and the concomitant sectarian violence, with its devastating consequences on Iraqi society. Saadawi explains: "Frankenstein in this novel is a condensed symbol of Iraq's current problems. The Frankenstein-esque atmosphere of 
horror was strongly prevalent in Iraq during the period covered by the novel" (Najjar, 2014).

Frankenstein in Baghdad introduces a new type of writing to the Arabic world. It won regional and international prizes including the IPAF in 2014 and the Man Booker. The book has been translated into more than twenty languages, which helped Iraqi fiction reach international recognition after decades of unproductivity under the totalitarian regime of the Baath. It has given global readers insight into the quotidian struggles of Iraqis, as experienced and witnessed by a local author who lives and writes from the midst of death and chaos. Besides, the success of the novel and the fame Saadawi gained in the Arab and International domain show how chaos has been a source of creativity for literature. This supports the view that chaos can be a motive for imagination and creative ideas.

\section{Art as a response to chaos}

To show another connection between creativeness and chaos, this section focuses on the Iraqi artist and painter Mahmoud Fahmi. Qasim Sabti, the director of the Iraqi Plastic Arts Society, notes that since the war finished "there is more [art] and more interest in art", and adds that "this jack-in-thebox will burst open, because we have talented people" (Scott, 2017). Despite the disorder of the conflict, the war has not reduced the creativity of artists in Iraq, in fact, on the contrary, Iraqi artists have become stubbornly productive and creative. Chaos and violence have motivated them to employ art to illuminate people's minds despite the difficult challenges in reality. Iraqi artists have overcome the crisis of motivation that afflicted Iraqi culture and art for decades because of the political censorship and lack of freedom of expression. This includes the Iraqi surrealist artist Muayad Muhsin whose paintings reflect on the present and past of Iraq; the Iraqi artist Nadia Osi and her paintings that focus on Iraqi heritage, culture and traditions through the joyous use of colour and attention to detail; and the paintings of 
Mahmoud Fahmi, another excellent example that illustrates how an artist can be creative during the time of chaos and war.

Mahmoud Fahmi (1962) is an Iraqi artist based in Canada. His paintings are unique as they feature the local culture of Iraq in a narrative style and vibrant colours. Fahmi employs different objects that represent Iraq's culture, such as water birds, watermelons, old vehicles, old radios, bicycles, rugs, kites, boats, and traditional food. Another unique characteristic in his art is the celebration of women, nature and magical elements. For example, a work by Fahmi might introduce a Baghdadi setting and a giant woman in a colourful dress sitting on the top of a building or flying on a magical rug.

One of the best examples of how Fahmi projects hope and positiveness through his art is his portrait The Return of Baghdad's Storks (Figure 1). In Arab culture, storks are a symbol of peace and positivity. When storks come to build their nests in a place or a city, this means that the location has become peaceful and safe. When Fahmi was working on this painting, Baghdad was threatened by security concerns and poor living standards. However, Fahmi's work projects hope and optimism through the use of lively colours and cheerful images as pointed out by the Iraqi artist alKhashaab (2015):

The misery, inhumanity and darkness of reality are manifested through the spread of cruelty, terror, exploitation and loss. These facts formed rich motives for the artist Mahmoud and pushed him to find lively artistic worlds that parallel this negative reality. He rejects negative restrictions and gave reality the familiarity and balance it needed.

The creative imagination reflected in Fahmi's works was driven by the artist's need to grasp the image of peaceful Baghdad while it was suffering the ravages of war. It was necessary for him to flee the unfortunate reality of his home to a world of imagination where the picture of Baghdad is as he wishes to see it. Fahmi, thus, creatively employs chaos, giving the girl 
sleeping on the roof of the house a size larger than the size of the house itself. Her satin dress in bright pink; the city that lies very quietly under a bright daytime sun; the sky ornamented with flying birds; the blue car in front of the house; the white storks that feel the safety and peace as they return to their nests to enjoy the areas beauty and stability; and the dark pink flowers on the right side of the painting that reflect happiness and joy. All these beautifully blended elements show how the Iraqi artist can be imaginative and creative in response to chaos and disorder.

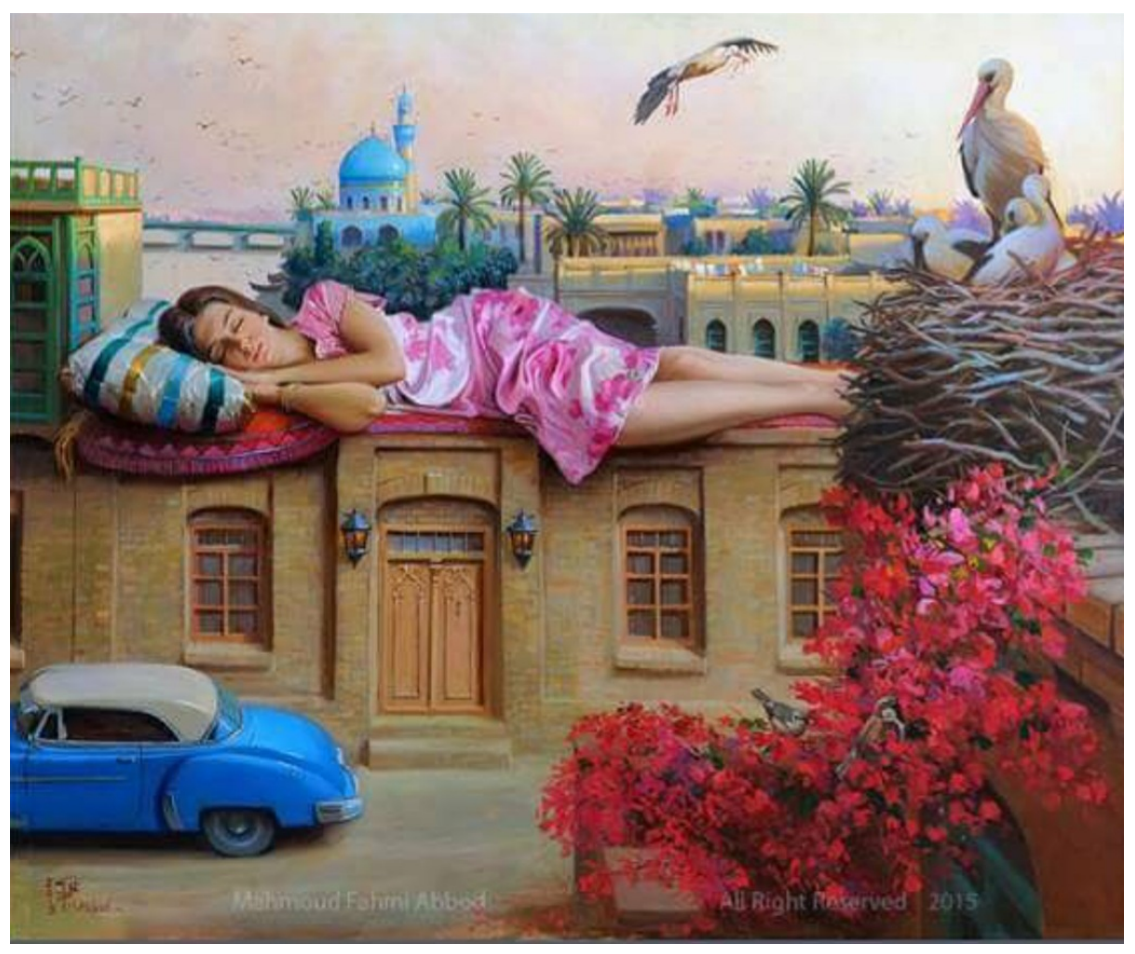

Figure 1: The Return of Baghdad's Storks (Fahmi, 2015).

\section{Conclusion}

I have selected two works of fiction and art that emerged in the post-2003 war Iraq in an attempt to show how the chaos, violence, and war have motivated authors and artists to be creative, reorder their thoughts, and 
express the predicament of their people in new ways that would have been previously unimaginable (had their experiences not taken place). Iraq's writers, like Ahmad Saadawi, have been stubbornly productive and creative during the years of chaos. The creative works presented by Iraqi painters like Mahmoud Fahmi show how artists are aiming to experience a degree of regularity in the midst of disorder, in which they make an active effort to preserve the beautiful image of their homeland during the years of peace and prosperity. Their works show how imagination can spring from chaos to describe it, embrace it, or suggest certain ways to resist it.

\section{References}

al-Alousi, H. M. E. (1968). The Problem of creation in Islamic thought, Qur'an, Hadith, commentaries, and Kalam. Bagdad: National Printing and Publishing.

al-Khashaab, W. (2015) A reading of The Return of the Storks painting by Mahmoud Fahmy Aboud. Available at: http://www.alnoor.se/article.asp?id=277086 (Accessed: 13 September 2020).

Arango, T. (2013) 'Car bomb epidemic is the new normal in Iraq', New York Times, 3 September. Available at: http://nytimes.com/2013/o9/04/world/middleeast/car -bomb-epidemic-is-the-new-normal-in-iraq.html (Accessed: 27 February 2020).

Edwards, D. (2020). 'Chaos, religious and philosophical aspects', Encyclopedia of Science and Religion. Available at: https://www.encyclopedia.com/education/ encyclopedias-almanacs-transcripts-and-maps/chaos-religious-andphilosophical-aspects (Accessed: 13 August 2020).

Hankir, Z. (2018) 'Ahmed Saadawi wants to tell a new story about the war in Iraq', Literary Hub, June 19. Available at: https://lithub.com/ahmed-saadawi-wants-totell-a-new-story-about-the-war-in-iraq (Accessed: 2 August 2020).

Hayles, N. K. (ed.) (1991) Chaos and order: complex dynamics in literature and science. Chicago: University of Chicago Press.

Ibrahim, S. (2012) 'al-Riwaya al-Iraqiyya: Rasd al-kharab (The Iraqi Novel: An Account of Destruction)', Tabayyun. 
Ibrahim, S. (2003) Jamharat maqalaat albrofesor mahmoud shakir (The articles of Professor Mahmoud Shaker Part 2). Cairo: Collected and presented by Adel Suleiman Jamal. Al-khanji printing house.

Lloyd, P. (2019 November) 'No creativity without chaos', ideaCONNECTION: Build on the Genius of Others. Available at: https://www.ideaconnection.com/right-brainworkouts/o0197-no-creativity-without-chaos.html (Accessed: 20 August 2020).

Leeming, D. (2005) The Oxford companion to world mythology. Oxford: Oxford University Press.

Legge, J. (1962). The texts of Taoism, Volume 1. The sacred books of China. New York: Courier Corporation.

Mark, J. J. (2018) 'Enuma Elisha - The Babylonian Epic of Creation'. Available at: https://www.ancient.eu/article/225/enuma-elish---the-babylonian-epic-ofcreation---fu/ (Accessed: 28 August 2020).

Mustafa, S. (ed) (2008) Contemporary Iraqi fiction: an anthology. Syracuse: University Press.

Najjar, A-M. (2014) 'Iraqi author Ahmad Saadawi: 'The novel implicitly questions this concept of salvation', Arabic Literature. Available at: http://arablit.org/2014/o3/26/iraqi-author-ahmad-saadawi-the-novelimplicitly-questions-this-concept-of-salvation/ (Accessed: 30 August 2020).

Omvedt, G. (2003) Buddhism in India: challenging Brahmanism and Caste. New Delhi: SAGE.

Peterson, S. (2017) 'In Iraq, artists work toward a post-war revival', The Christian Science Monitor. Available at: https://www.csmonitor.com/World/MiddleEast/2017/1128/In-Iraq-artists-work-toward-a-postwar-revival (Accessed: 28 August 2020).

Torre, C. A. (2014) 'Chaos, creativity, and innovation: toward a dynamical model of problem solving', in Robertson, R. and Combs, A. (eds) Chaos theory in psychology and the life sciences. New York: Psychology Press, pp. 179-198.

Zangana, H. (2007) City of widows: an Iraqi woman's account of war and destruction. New York: Seven Stories Press. 